Journal of Southeast Asian

\title{
Book Review: Identity Construction Among Chinese-Vietnamese Americans by Monica Trieu
}

Ha Lam

Arizona State University, hlam1@asu.edu

Follow this and additional works at: https://docs.lib.purdue.edu/jsaaea

Part of the Sociology Commons

\section{Recommended Citation}

Lam, $\mathrm{Ha}$ (2010) "Book Review: Identity Construction Among Chinese-Vietnamese Americans by Monica Trieu," Journal of Southeast Asian American Education and Advancement. Vol. 5 : Iss. 1, Article 10. DOI: 10.7771/2153-8999.1011

Available at: https://docs.lib.purdue.edu/jsaaea/vol5/iss1/10

This document has been made available through Purdue e-Pubs, a service of the Purdue University Libraries. Please contact epubs@purdue.edu for additional information.

This is an Open Access journal. This means that it uses a funding model that does not charge readers or their institutions for access. Readers may freely read, download, copy, distribute, print, search, or link to the full texts of articles. This journal is covered under the CC BY-NC-ND license. 


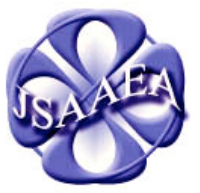

Volume 5 (2010)
Journal of Southeast Asian American

Education \& Advancement

WWw.JSAAEA.org
A peer-reviewed

scholarly journal published by the National Association for the Education \& Advancement of Cambodian, Laotian, and Vietnamese Americans (NAFEA)

Trieu, M. M. (2009). Identity construction among Chinese-Vietnamese Americans: Being, becoming, and belonging. El Paso, TX: LFB Scholarly Publishing LLC. 220 pp. $\$ 62.00$ (hardback). ISBN: 9781593323745

\author{
Reviewed by \\ Ha Lam \\ Arizona State University
}

Among the research that has been conducted on Asian Americans, a limited number of studies have focused on Vietnamese Americans. Of these, even fewer have taken the time to

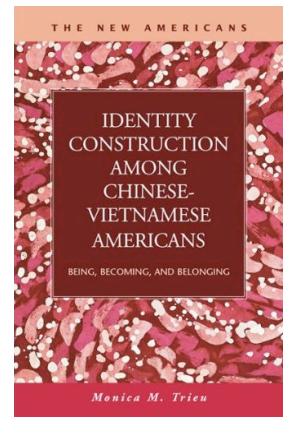
differentiate the experiences of Chinese-Vietnamese Americans from Vietnamese Americans. As such, Monica Trieu's book, Identity Construction Among Chinese-Vietnamese Americans: Being, Becoming, and Belonging, represents a timely contribution to the field as one of the few studies that specifically focus on the Chinese-Vietnamese experience in the United States. The author believes that a primary reason that there is so little research focusing on Chinese-Vietnamese is that researchers have a hard time identifying this population. For example, Yu and Liu (1986, p. 489) decided to omit Chinese-Vietnamese from their study because:

$[\mathrm{H}]$ ow does one classify a Chinese who grew up in Vietnam, attended Chinese school and cannot speak Vietnamese fluently? Does it matter to the Chinese, he is perceived as Vietnamese and to the Vietnamese, he is perceived as Chinese? Is self-definition of ethnic identity preferable to racial or biological definitions of identity? (as cited in Trieu, p. 48)

Trieu acknowledges the difficulty with studying the Chinese-Vietnamese as a disaggregated ethnic population because it is less of a "straightforward ethnic identity." Whereas the author was able to easily find the demographic information for Vietnamese Americans, she had to tease out publicly available data to identify who was Chinese-Vietnamese.

The first chapter gives a brief introduction to the study and lays out the key research questions. Her main focus is to analyze the experiences of 1.5 and $2^{\text {nd }}$ generation ChineseVietnamese Americans and includes data on Vietnamese Americans as a comparison group. Specifically, the study asks: (a) How do the children of Chinese and Vietnamese ancestry select, assert, and navigate their ethnic or intra-ethnic identity? (b) What contextual factors influence the

\title{
@)
}

SOMERIGHISRESERED Readers are free to copy, display, and distribute this article, as long as the work is attributed to the author(s) and the Journal of Southeast Asian American Education \& Advancement, it is distributed for noncommercial purposes only, and no alteration or transformation is made in the work. More details of this Creative Commons license are available at http://creativecommons.org/licenses/by-nc-nd/3.0/. All other uses must be approved by the author(s) or JSAAEA. 
social construction of an ethnic and/or racial identity for intra-national ethnics? (c) Is ethnic identity discarded and replaced by symbolic ethnicity?

In chapter 2, Trieu gives a brief historical sketch of Vietnamese Americans and ChineseVietnamese Americans and includes background information about relations between Vietnam and China. The following chapter provides a theoretical overview of ethnicity and assimilation, the social construction of ethnicity and ethnic groups, and existing literature focusing on Chinese-Vietnamese. The author argues that the idea of ethnicization and intra-national ethnicity is important in understanding Chinese-Vietnamese Americans. Ethnicization occurs due to "immigrant sub-ethnic groups internalizing ethnic labels assigned by larger society" and "immigrant sub-ethnic groups unifying to combat common struggles that they face as a group" (p. 45). Trieu asserts that it is important to look at immigrant groups' experiences in their home country and whether they had majority status or minority status in their country of origin. For example, many ethnic Chinese living in Vietnam tended to be very proud of their Chinese heritage and resisted adopting a Vietnamese identity despite pressure and persecution from the Vietnamese government. Since the Chinese-Vietnamese did not have majority status in Vietnam, they are considered "twice minorities" upon immigration to the United States. As the author notes, Yen Le Espirtu has hypothesized that "twice minorities" are "not fragmented and weak upon arrival" (p. 46) because they have already gone through ethnicization in their home country.

In chapter 4, Trieu discusses the study's methodology and reflects on her co-ethnic researcher status. Particularly interesting were Trieu's reflections on how her own ethnic background might affect the study:

Would my role, as Chinese-Vietnamese researcher, be compromised because of my ethnicity? Would I overlook something because of my own personal background? Would my role as a graduate student affect their responses to me? Would the respondents be less apt to open up to me because they view me as a fellow co-ethnic? I was aware that being Chinese-Vietnamese myself could impact how I view, influence, and interpret the data that I collected. (p. 69)

The author admitted that she at times felt uncomfortable as a co-ethnic researcher because "there were respondents who tried to turn the tables around during the interview" (p. 70) and ask about her own experiences growing up as a Chinese-Vietnamese in the United States. As a ChineseVietnamese researcher myself, I, too, have wondered whether I would influence participants by sharing my experiences with them. Trieu notes that several respondents would speak to her in Cantonese, Vietnamese, or Teochiu and "appeared immediately more comfortable when I understood them. Other respondents took for granted that I would understand them" (p. 70). However, it is only in the final chapter that Trieu shares more about her personal story of immigrating to the U.S. and that she did not know that she is ethnically Teochiu and not Cantonese until she was a teenager. It would have been helpful to have more discussion about what being Teochiu meant as many readers are unlikely to be familiar with this ethnic and linguistic group. It might also have been useful for Trieu to begin the book with her personal story or to have incorporated it into the methodology section when discussing her insider/outsider status since it is an important part of why she pursued the study.

Since the study focused on participants in California (Los Angeles County and Orange County), Trieu provides readers in chapter 5 with a quick demographic profile of the Chinese- 
Vietnamese and Vietnamese American community in California. The largest Vietnamese American community is situated in Orange County, California. However, of the total ChineseVietnamese population in the U.S., 25 percent reside in nearby Los Angeles County. One key finding of language use among Chinese-Vietnamese is that a higher percentage speak Chinese rather than Vietnamese when comparing across generations and regions except for the second generation. Second generation Chinese-Vietnamese who live in Los Angeles County tend to speak Chinese whereas those who live in Orange County tend to speak Vietnamese. Furthermore, regardless of generation, the proportions of Chinese-Vietnamese who live in Los Angeles tend to speak more Chinese than those who live in Orange County and the percentage of Chinese-Vietnamese who speak Vietnamese is higher in Orange County than in Los Angeles. Other research has found that for each half-generation living in the U.S., the percentage of English language use increases and ethnic language use decreases. For example, 96 percent of first-generation speak Vietnamese, 86 percent of 1.5 generation Vietnamese-Americans speak Vietnamese, and only 58 percent of the second-generation speak Vietnamese. This pattern is similar for the Chinese-Vietnamese. Trieu's data supports other studies (Veltman, 1999; Fishman, 2001) that have found language shift is occurring among today's immigrants.

Trieu's findings regarding location and language use in chapter 5 are especially interesting in light of her discussion on the impact of location and how the neighborhood context influences ethnic identity choices in chapter 6 . She found that ethnic identity choice correlates with location since location impacts the availability of ethnic resources, family motivation, and peer influences. Trieu found that for Chinese-Vietnamese growing up in Orange County, the most instrumental factor in determining early identity formation was their desire to be accepted by their peers. Many of the respondents chose to pass as Vietnamese in order to fit in with their peers versus asserting their Chinese-Vietnamese identity. A common theme among many respondents was that of identity shift in which they went through periods of identifying as Vietnamese, Chinese, and Chinese-Vietnamese. For the Chinese-Vietnamese who grew up in Los Angeles County, the two strongest factors that influenced their identity choices were the role of family and availability of Chinese ethnic resources and networks.

A key difference between Chinese-Vietnamese and Vietnamese Americans is that Vietnamese Americans rarely questioned their Vietnamese identity. The big question for Vietnamese Americans was whether or not to embrace their Vietnamese identity. Not surprisingly, Trieu found that Vietnamese Americans who participated in Vietnamese community organizations tended to report a stronger ethnic identity and that Vietnamese Americans who lived in Orange County had various Vietnamese resources available to them. However, many Vietnamese-Americans who lived in Los Angeles County, having fewer ethnic sources of community support, as a consequence, "felt isolated from the community and in turn expressed ethnic self-hatred during their youth" (p. 113). This last finding is surprising to me because having grown up on the East Coast I assumed that Vietnamese resources in California would be plentiful and available, given the size of the state's Vietnamese communities.

In chapter 7, Trieu looks at the cultural context (i.e., language and ethnic celebrations) of ethnic identity construction. A key finding is that both parental language use and knowledge of cultural traditions seems to be eroding for both groups. While respondents vary in their ability to speak the ethnic language(s) - some are fluent while others only know some phrases - many have lost or never acquired the ability to read and write in the ethnic language(s). One interesting finding between the Chinese-Vietnamese and Vietnamese Americans was the different ways they spoke about the ethnic language. For the Chinese-Vietnamese, language was a crucial factor that 
influenced their early-life ethnic identification choice. For the majority of Chinese-Vietnamese respondents, whatever language they spoke at home determined what ethnic identity they selfidentified as in their youth. Whereas language had a profound impact on how many ChineseVietnamese identified themselves ethnically, for Vietnamese Americans, language was viewed as a means to connect with the ancestral culture and the older generation.

While many respondents from both groups expressed a desire to pass on their ethnic culture, celebrations, and traditions to their children, many stated they do not know enough to do so. However, 68 percent of respondents who feel they do not know enough about their ethnic culture stated they are willing to learn. Others shared that they were not exposed to ethnic celebrations and will not try to pass it on. Only time will tell if the 1.5 and second-generation will be able to pass on cultural knowledge to the next generation. As it stands now, ethnic celebrations seem to be shifting towards "generalized cultural knowledge" for both groups since the majority does not know the reasons for celebrating the holidays nor the specific rituals to perform to celebrate the holidays.

Chapter 8 examines how the college context (e.g., participation in Asian American Studies and/or ethnic organizations) helped influence ethnic/racial identity formation and choices of Chinese-Vietnamese and Vietnamese Americans. Trieu found that an overwhelming majority from both groups have either taken Asian American studies courses and/or joined an ethnic organization (59\% of Chinese-Vietnamese; $83 \%$ of Vietnamese Americans) and more than half of them asserted that taking Asian American studies classes and/or participating in an ethnic organization "played a pivotal role in their identity formation" (p. 148). It would have been interesting if she had examined why such a higher percentage of Vietnamese Americans participated in Asian American studies and/or ethnic organizations as compared to ChineseVietnamese. As ethnic language played a different role for the two groups, participation in Asian American studies and/or ethnic organizations also served different purposes. For the Chinese-Vietnamese, it exposed the multiple histories that they were able to identify with, whereas for the Vietnamese Americans, it served as a space for them to better understand their experiences growing up and their positioning in the U.S.

In the book's final chapter, Trieu summarizes her findings, discusses theoretical and policy implications, and suggests topics for future research. Trieu also shares her family's story of fleeing from Vietnam and adapting to life in the U.S. and how this helped to shape her research study and her struggles with ethnic identity. Overall, it is exciting for me as a ChineseVietnamese American to see a whole study devoted to the identity construction of ChineseVietnamese in the United States. This book will be useful to those interested in delving into the complexities of language, culture, and identity, particularly scholars in sociology, education, history, and ethnic studies.

However, as Trieu notes herself, the majority of studies that have focused on ChineseVietnamese Americans and/or Vietnamese Americans have focused on these populations in California. Since one of the key findings of this study is the importance of geographic location on the 1.5 and second generation's choice of identity, it would be interesting for future studies to examine the experiences of other 1.5 and second generation Chinese-Vietnamese and Vietnamese Americans outside of California - perhaps on the East Coast and/or in areas where there is limited access to ethnic resources and networks. Would they experience similar feelings of ethnic self-hatred or identity shifting as did those in this book? 


\section{References}

Fishman, J. (2001). 300-plus years of heritage language education in the United States. In J. K. Peyton, D. Ranard, \& S. McGinnis (Eds.), Heritage languages in America: Preserving a national resource (pp. 81-97). McHenry, IL: Center for Applied Linguistics and Delta Systems.

Veltman, C. (1999). The American linguistic mosaic. In S. L. McKay \& S. C. Wong (Eds.), New immigrants in the United States (pp. 58-93). Cambridge, UK: Cambridge University Press.

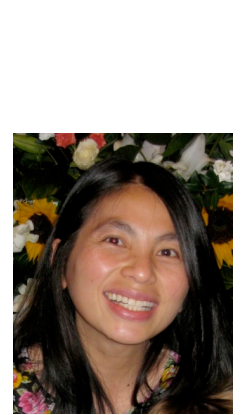

\section{About the Reviewer}

Ha Lam is a PhD candidate in Curriculum \& Instruction with a specialty in Language \& Literacy at Arizona State University. Her research interests include ESL, heritage language loss and maintenance, and language policy. She has taught at the elementary school, middle school, high school, and college level as well as adults in the U.S. and in Japan. 


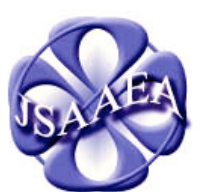

Volume 5 (2010)

\section{Journal of Southeast Asian American Education \& Advancement}

WWW.JSAAEA.org
A peer-reviewed scholarly journal published by the National Association for the Education \& Advancement of Cambodian, Laotian, and Vietnamese Americans (NAFEA)

\author{
Editor \\ Dr. Wayne E. Wright \\ University of Texas, San Antonio \\ Associate Editors \\ Dr. Chhany Sak-Humphry \\ University of Hawaii \\ Dr. KimOanh Nguyen-Lam \\ California State University, Long Beach \\ Book Review Editor \\ Dr. Vichet Chhuon \\ University of Minnesota \\ Creative Works Editor \\ Bryan Thao Worra \\ Lao Assistance Center \\ Special Advisor \\ Gregory Green \\ Curator, Echols Collection on Southeast Asia, Cornell University Library \\ Journal Manager \\ Sovicheth Boun \\ University of Texas, San Antonio
}

Comments and questions for the editorial staff may be directed to jsaaea@1ists.sis.utsa.edu

\title{
Editorial Review Board
}

Dr. Carl L. Bankston III

Tulane University

Dr. Phala Chea

Lowell Public Schools

Dr. Loan Dao

Cancer Prevention Institute of California

Dr. Sophal Ear

U.S. Naval Postgraduate School

Dr. Samlong Inthaly

Minneapolis Public Schools

Dr. Kevin K. Kumashiro

University of Illinois, Chicago
Dr. Pollie Bith-Melander

Asian and Pacific Islander Wellness Center

Dr. George Chigas

University of Massachusetts, Lowell

Dr. Changming Duan

University of Missouri, Kansas City

Dr. Nancy H. Hornberger

University of Pennsylvania

Dr. Peter Nien-Chu Kiang

University of Massachusetts, Boston

Dr. Stacey Lee

University of Wisconsin, Madison 


Dr. David Chanpannha Ley
Montgomery County Public Schools
Dr. Bic Ngo
University of Minnesota
Dr. Leakhena Nou
California State University, Long Beach
Dr. Mark Pfeifer
Texas A\&M University, Corpus Christi
Dr. Bounlieng Phommasouvanh
Minnesota Department of Education
Dr. Kalyani Rai
University of Wisconsin, Milwaukee
Dr. Nancy J. Smith-Hefner
Boston University
Dr. Loan Tran
Center for Applied Linguistics
University of California, Riverside
Dr. Khatharya Um

Dr. Sue Needham

California State University, Dominguez Hills

Dr. Max Niedzwiecki

Daylight Consulting Group

Dr. Clara Park

California State University, Northridge

Dr. Loan T. Phan

University of New Hampshire

Dr. Karen Quintiliani

California State University, Long Beach

Dr. Fay Shin

California State University, Long Beach

Dr. Yer J. Thao

Portland State University

Dr. Myluong Tran

San Diego State University

Dr. Linda Trinh Vo

University of California, Irvine

Dr. Zha Blong Xiong

University of Minnesota

Dr. Kou Yang

California State University, Stanislaus

\section{Doctoral Student Editorial Review Board}

\author{
Keo Chea-Young \\ University of Pennsylvania \\ Peter Tan Keo \\ Columbia University \\ Ha Lam \\ Arizona State University \\ Monirith Ly \\ Texas State University-San Marcos \\ Malaphone Phommasa \\ University of California, Santa Barbara \\ Rassamichanh Souryasack \\ University of California, Santa Barbara \\ Layheng Ting \\ State University of New York, Albany \\ Tinou Tran \\ University of Houston, Texas \\ Phitsamay Sychitkokhong Uy \\ Harvard University
}

Annie BichLoan Duong

San Joaquin County Office of Education

Polinda Keo

University at Albany

Ravy Lao

University of California, Santa Barbara

Giang Pham

University of Minnesota

Vanna Som

Harvard University

Somongkol Teng

University of Minnesota

\author{
Alisia Tran \\ University of Minnesota \\ Silvy Un \\ University of Minnesota \\ Yang Sao Xiong \\ University of California, Los Angeles
}

